\title{
Biomass as a Renewable Resource for Energy and Chemical Products
}

\author{
Otun Saha*, Afroza Sultana, Nikkon Sarker, Md. Ashfaqur Rahman Siddiqui, Foysal Hossen, \\ Sanjoy Kumar Mukharjee
}

Department of Microbiology, Noakhali Science and Technology University, Noakhali, Bangladesh

\author{
Email address: \\ otun.saha@gmail.com (O.Saha) \\ ${ }^{*}$ Corresponding author
}

\section{To cite this article:}

Otun Saha, Afroza Sultana, Nikkon Sarker, Md. Ashfaqur Rahman Siddiqui, Foysal Hossen, Sanjoy Kumar Mukharjee. Biomass as a Renewable Resource for Energy and Chemical Products. Science Journal of Energy Engineering. Vol. 5, No. 6, 2017 , pp. $146-151$. doi: $10.11648 /$ j.sjee.20170506.13

Received: April 12, 2017; Accepted: April 22, 2017; Published: November 28, 2017

\begin{abstract}
Global demand for biomass-based products will increase over the next decades. Global biomass demand is expected to roughly double between 2020 and 2050. In addition to ensuring food security for a growing and richer world population, biofuels and bio-based materials will increasingly drive future demand. This lead to a greater utilization of renewable resources to replace the old and existing fossil-based feedstock for energy and chemicals. In addition to depleting fossil fuel reserves and growing demand for energy has necessitated the renewed search for alternative energy resources such as sunflower seeds, soybean, canola, peanuts, coconut, wheat, sugar beet, and sweet sorghum etc. as well as Biomass. Bioethanol, biodiesel, and biogas are the most common form of energy getting forms various biomass sources. On the other hand's glycerol, furans, levulinic acid, and aliphatic acids are the most common form of chemical generating from biomass using the various process as well as through the action of microorganisms and their enzymes. In the case of Bangladesh the main energy sources biomass and natural gas where biomass energy is about $70 \%$ of the total energy consumption. On the other hand, in the case of chemical production using biomass Bangladesh is not so much updated than the others developing countries around the world. This review represents the biomass sources and from them which various valuable chemicals and energy products are produced as well as biomass as a renewable resource for energy and chemical products.
\end{abstract}

Keywords: Biomass, Renewables, Biodiesel, Bioethanol, Tran's Esterification

\section{Introduction}

In preindustrial era until the 19th century, renewable raw materials were the major source of energy and material use. In the 20th century, there has been a changeover in fossil fuel sources from coal to crude oil and natural gas due to lower prices, simpler logistics and the versatility in the usage of oil and gas. In connection with the limited availability and increasing price of crude oil and natural gas, the question now arises how to face this situation and what raw material base will develop in the future? Biomass as a renewable raw material could be the answer $[1,2]$. Biomass is a generic term for all vegetable material. It is generally a term for material derived from growing plants or from animal manure [3]. According to it, "Biomass means the biodegradable fraction of products, waste, and residues from the biological origin from agriculture (including vegetables and animal substances), forestry and related industries including fisheries and aquaculture, as well as the biodegradable fraction of industrial and municipal waste". Biomass has a unique characteristic compared with other forms of renewable energy. More specifically, biomass includes any organic matter that is available on a renewable or recurring basis, such as energy crops and trees, agricultural food and food crop residues, aquatic plants, wood and residues, animal waste, and other waste materials [4]. Cellulose, hemicelluloses, and lignin compose the biomass present in wood, grasses, stalks, and straw, for instance. Starch and cellulose are polysaccharides consisting of hexose units; hemicellulose is a heteropolysaccharide made of a mixture of pentose and hexose monomers; lignin is a complex three- 
dimensional polymer formed by phenolic compounds, and oils consist of triglycerides. Other biomass components, which generally exist in minor amounts and are usually designated secondary metabolites, include alkaloids, carotenoids, flavonoids, phenols, resins, sterols, tannins, terpenes, and waxes, among others [4]. The main components of wood biomass are Cellulose (35\% to 50\%), Hemicelluloses $(20 \%$ to $35 \%$ ), Lignin $(5 \%$ to $30 \%)$, and Others extracted compounds ( $1 \%$ to $10 \%)[5,6]$.

\section{Literature Review}

In this review, scientific literature including evidence in the form of published scientific papers, concentrating on the literature since the last set of data was published around 2016 were used to get a perspective on this topic. Computerized literature searches of PubMed were performed. Human studies in the English language literature were searched very carefully to ensure that all relevant literature was captured in this article. Individual terms and combinations, such as Biomass, sources, renewable energy, chemicals etc. were used. Lastly, numerous review of various different international papers including for the use of biomass as energy and chemicals source published within some years in which similar parameters were recommended in all the paper are followed.

\section{Biomass as Renewable Sources}

Renewable resources are generally regarded as natural resources which are naturally replaced over a period of time [7]. Resources such as solar radiation, tides, winds and other natural elements as well as biomass are renewable resources of energy and chemicals are now called renewable resources
[8]. According to the EIA's International Energy Outlook [9]. world marketed energy consumption is expected to increase strongly, rising by nearly 50 percent from 2009 through 2035. We can also find the similar types of arguments in the report of IEA. According to the report of International Energy Agency (IEA 2013) global energy consumption (Biomass 10.0\%, Nuclear 5.1\%, Hydropower 2.3\% Oil $31.5 \%$, Nuclear gas $21.3 \%$ and coal $28.8 \%$ ) is increasing dramatically, for this reasons recent times pressures on the global environment have led to calls for an increased use of renewable energy sources. That's why to manage this types of requirement its high time to look at Biomass. There are several types of biomass which have to be treated in a specific way to produce materials, chemicals, and energy. They are Wood, plant lignocellulose [10, 11]; Soybean [11, 12]; Sugar beet, sugar cane [12]; Corn, wheat [13]; Algae, water weed [14] etc.

\subsection{Biomass for Chemical Products}

Biomass can not only provide fuel and energy, but it also can be a source for the production of countless biochemical (Table 1) that can be used as, among other things, paints, detergents, industrial adhesives, bioplastics, and composite materials. There are numerous ways to obtain chemicals from biomass. Biochemical such as cellulose and starch derivative chemicals, glucose, glycerol, citric acid, and lactic acid can be obtained by chemical modifications and fermentation [8]. These include [15] Oil, Carbohydrates- sugars, starch, cellulose, hemicellulose, Lignin, Protein, Waxes and Secondary metabolites. A number of valuable aliphatic acids can be produced either by biological or chemical pathways [16].

Table 1. Some of the major common chemical compounds identified from different biomass sources [49, 50, and 51]

\begin{tabular}{llll}
\hline Acids & Acetic acid & Sugars & A-d-Glucopyranose \\
\hline & Formic acid & & $1,4,3,6$-dianhydro \\
& Propanoic acid & Arabinofuranose \\
Aldehudes & Aliphatic acids & & 5 -anhydro \\
& Acetaldehyde & Benzene \\
& Formaldehyde & Catechols & Hydroquinone \\
Fyrans & Propanal,3-hydroxy3 & & 1,4 -dihydroxy-benzene \\
& Furan,2,5dimethyl & Maltol \\
& 2-Furanmethanol & Phenol & Sanillin \\
& 2H-pyran,3,4-dihydro & & Syringyl acetone \\
& 3.methyl -furanoe & & 2-methyl phenol \\
& (3H)-furanone,5 & & 3 -methyl phenol \\
\hline
\end{tabular}

Acetic acid is produced both by chemical synthesis and by fermentation processes. In biocatalytic processes, acetic acid is produced either by oxidative fermentation of ethanol using Acetobacter or via the direct fermentation of sugar to acetic acid. According to F. Jin and his co-workers higher yield of acetic acid from biomass waste that is $0.79 \mathrm{~g} /{ }^{1}$ [17]. Another important acid used in the industry is lactic acid, and this can be produced from various sources but also various biomass including corn, wheat, potato, cassava, rice, sweet sorghum etc $[18,19]$ Various types of microbes are involved in this production process this includes Rhizopus sp. [20]; Lactobacillus sp. [21] and much more. In the research works of Wang gets.86g/1 lactic acid [22] from biomass whereas Giro gets $73 \mathrm{~g} / 1$ [23]. In another study, a novel strain Streptococcus bovis 148 was used to produce $14.2 \mathrm{~g} / \mathrm{l}$ lactic acid directly from starch [24].

Glycerol can be produced from biomass via transesterification of triglycerides from fats and oils [25]. Base catalysts give higher rates than acid catalysts. Alternatively, glycerol can be obtained as a by-product from 
the fermentation of glucose and fructose into ethanol (e.g., using Saccharomyces cerevisiae) from various agricultural waste products' [26]. In some study, $1.04 \mathrm{~g} / 1$ and $2.73 \mathrm{~g} / 1$ glycerol were generated from various biomass including agricultural wastes and wood waste $[18,25]$.

Organic acids such as levulinic acid and furans can be produced through acid-catalyzed dehydration and hydrolysis of hexose and pentose sugars. These are the predominant sugars found in the carbohydrate content of lignocellulosic materials (cellulose and hemicellulose) as well as other biomass sources (starch, chitin, etc.) yields of $60 \%-70 \%$ under stripping [27].

\subsection{Global Prospect of Biomass as Renewable Energy Sources}

Various types of sources are contributing into global energy (Figure: 1). Among them the use of biomass to provide energy has been fundamental to the development of civilization. Biomass is the most dominant renewable energy source used in the world today, comprising almost 80 percent of the total supply [28]. Currently, the biomass comprises 10.6 percent of the world's total energy supply [28]. With 30 percent of the Earth's surface covered in forest lands, forest residues could play a more significant role in the amount of biomass produced and used globally. To increase the use of biomass for energy, the EU has developed common energy guidelines and directives. These guidelines and directives are expected to have a significant positive effect on bioenergy use in the coming years. Some analysts have predicted an almost three-fold increase in the next 5-10 years [29]. Taking modern bioenergy into account; the major products of bioenergy are biodiesel and bioethanol.

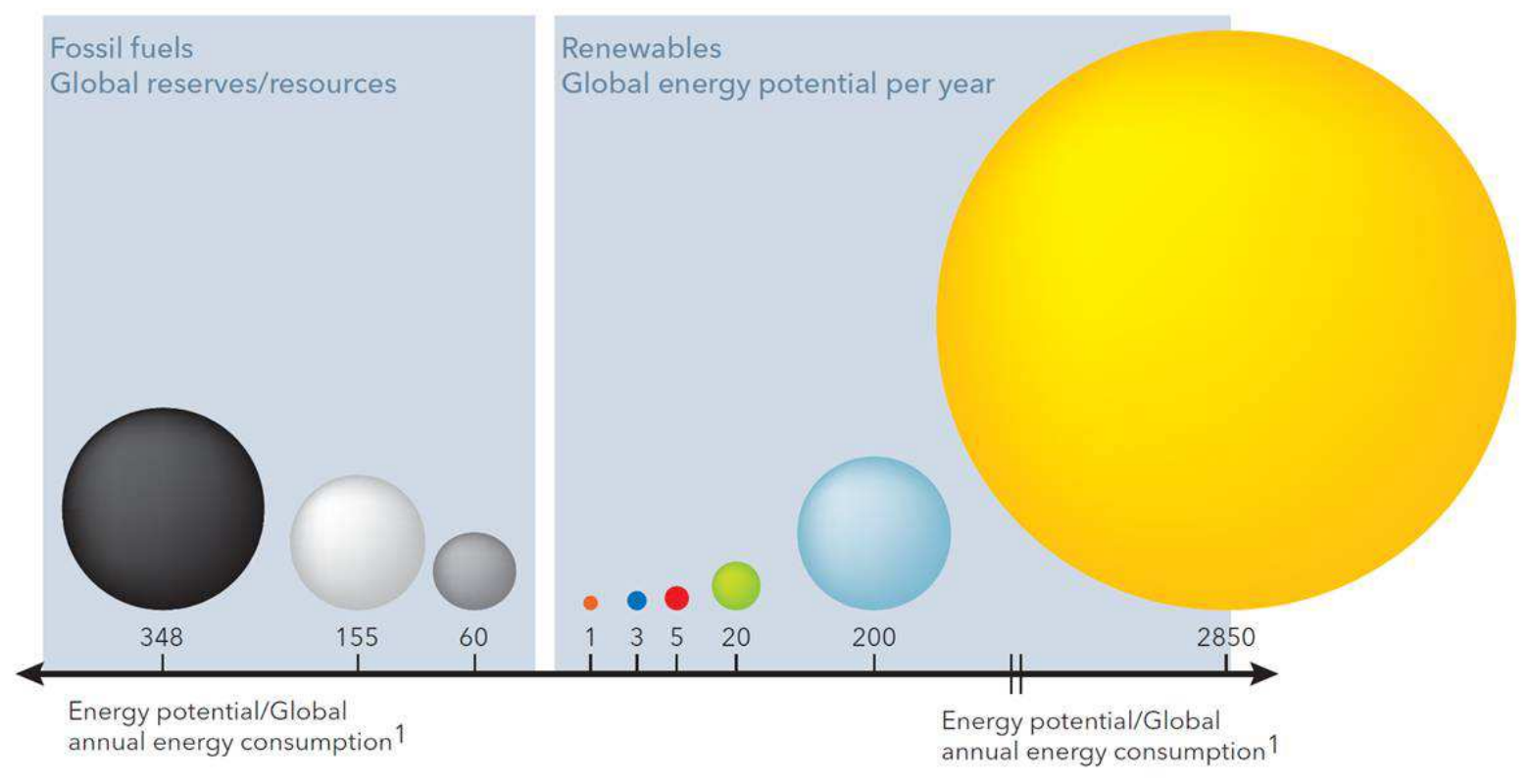

\begin{tabular}{|c|c|c|c|c|c|}
\hline & $\begin{array}{l}\text { Energy potential } \\
\text { Reserves/Resources } 2\end{array}$ & $\begin{array}{l}\text { Thereof conven- } \\
\text { tionally utilizable }\end{array}$ & & $\begin{array}{l}\text { Energy potential } \\
(\text { amount of energy p. a.) })^{2}\end{array}$ & $\begin{array}{l}\text { technologically utiliz- } \\
\text { able (state of the art) }\end{array}$ \\
\hline Coal & $\sim 135.000 \mathrm{EJ}$ & & Solar radiation & $\sim 1.111 .500 \mathrm{EJ}$ & $\sim 1.482 \mathrm{EJ}$ \\
\hline Natural gas & $s \sim 60.400$ EJ & $\sim 12.000 \mathrm{EJ}$ & Wind energy & $\sim 78.000$ EJ & $\sim 195 \mathrm{EJ}$ \\
\hline Crude oil & $\sim 23.000$ EJ & $\sim 9.800 \mathrm{EJ}$ & Biomass & $\sim 7.800 \mathrm{EJ}$ & $\sim 156 \mathrm{EJ}$ \\
\hline \multirow{2}{*}{\multicolumn{3}{|c|}{ Global energy demand 2006: 470 EJ }} & Geothermal & $\sim 1.950 \mathrm{EJ}$ & $\sim 390 \mathrm{EJ}$ \\
\hline & & & Hydro/tide power & $\sim 1.170 \mathrm{EJ}$ & $\sim 78 \mathrm{EJ}$ \\
\hline
\end{tabular}

Figure 1. Global energy resources. source : Hessen-Nanotech (2008).

Biodiesel is prepared from various sources including edible oils, non-edible oils, animal fats, legume plants, etc. Generally, biodiesel (methyl/ethyl ester) fuels are produced by reacting vegetable oil (extracted from oilseed crops) or animal fat with methanol/ethanol and catalyzed by caustic soda. This process is called transesterifcation [30]. Currently, soybean oil is the dominant biomass source for biodiesel production [31]. Yellow grease, another cheap resource from which to make biodiesel is a form of low-grade oil that includes used frying oil or oil derived from animal fats. Biodiesel that is derived from virgin oils such as soybean oil is more resistant to cold weather when compared to the biodiesel derived from animal fat [32].

Biogas is a product of anaerobic degradation of organic substrates, which is used for the treatment of industrial wastes, cattle manure, agricultural waste, municipal solid waste etc. Peyman Abdeshahian and his groups was work on the production of biogas to using the farm animals (cows, buffalo, chicken, sheep etc.) waste and get the total amount of biogas produced 4589.493 million $\mathrm{m} 3 / \mathrm{yr}$ from it [33] whereas Rudianto Amirtaa and his groups gets 3100-3200 million $\mathrm{m} 3 / \mathrm{yr}$ from wood waste [34]. On other works, 
Arkadiusz Piwowar and Cristina Rodriguez gets 2800-3780 million $\mathrm{m} 3 / \mathrm{yr}$ [35] and 175-190 million $\mathrm{m} 3 / \mathrm{yr}$ [36] from agricultural waste and grasses respectively.

Ethanol was the first biofuel produced from food-based feedstocks such as corn and sugarcane. First generation bioethanol is produced from corn and sugarcane using a wellestablished technology [37] and the amount is about 2.8 gallons ethanol [38]. In some others research agricultural and wood residues (e.g., wood chips, corn Stover, sugarcane bagasse, and sawdust) [39] are also used.

\subsection{Algae as a Bioenergy Source}

Microalgae have a great diversity and there are about 300,000 species of microalgae. Microalgae possess the capability to be used as feedstocks for the production of biodiesel. These microalgae make up only 0.2 percent of global biomass generated through photosynthesis, they account for approximately 50 percent of the total global fixed organic carbon [40]. The potential biomass yield of algae per unit area is also often higher than that of terrestrial plants ${ }^{[41]}$ with, for example, brown seaweeds grown "under culture conditions" having yields of $\sim 13.1 \mathrm{~kg}$ dry weight $\mathrm{m}-2 \cdot \mathrm{yr}-1$ compared to $\sim 10 \mathrm{~kg}$ dry weight $\mathrm{m}-2 \cdot \mathrm{yr}-1$ from sugarcane [42]. Microalgae can provide several different types of renewable biofuels. These include methane produced by anaerobic digestion of the algal biomass [43] biodiesel derived from microalgal oil [44]; and photo biologically produced biohydrogen [45]; ethanol [46] etc.

\subsection{Current Challenges in Use of Biomass as Energy and Chemicals Sources}

Biomass is still an expensive source of energy and chemicals both in terms of producing biomass and converting it into valuable products, as a very large quantity of biomass is needed. This increased use of biomass can have detrimental impacts on air quality as well as the whole world. Wood burning, in particular, emits particulate matter (PM), benzene, benzo (a) pyrene $(\mathrm{BaP})$ and other substances into the air, with significant effects on human health, for instance asthma and respiratory diseases. The European Commission estimates that which are considered to cause 430000 premature deaths a year in the EU (European Parliament, 2013). The removal of residues (typically branches and tree tops left after feeling, as well as stumps and roots) for bioenergy can have an impact on soil properties. Extracting forest residues, which have a very high nutrient concentration, may affect soil quality, hinder natural regeneration and limit future production potential(European Environment Agency, 2013). On cropland, removing straw traditionally used as a soil improver may increase soil erosion, reduce water retention and limit soil temperature regulation (although it may be beneficial in some areas). A 2010 meta-study found that in temperate forests, (increased) harvesting results in an average $8 \%$ decrease in total soil carbon. Biomass extraction can also affect biodiversity, in particular through deforestation, degradation of forest ecosystems and conversion of natural forests to tree plantations. Residue harvesting may affect species living off biomass residues such as dead wood or crop roots. Changes in the structure of forest soils may induce harmful effects on biodiversity.

\subsection{Availability and Use of Biomass for Chemical and Energy Production in Bangladesh}

Bangladesh is an agriculture-based country and the available biomass is mainly of agricultural residues like rice husk \& rice straw from rice plants, Biogases from sugarcane, Jute stick, residues from Wheat, potato, oilseeds, spices etc [47]. In addition to the agricultural wastes the other sources are dry materials such as dry wood, dried leaf, charcoal, coconut shells etc. Over last 30 years, there has been an increasing trend of biomass fuel supply in Bangladesh. The total supply of biomass fuel was 236.08 PJ in 1980 and has increased over next 20 years to $356.66 \mathrm{PJ}$ (1.73\% growths). Traditional fuel supply usually comes from main three sources viz. crop residues, animal dung and trees [48]. The percentages of different traditional energy were as follows: Cow-dung 20.4\%, Jute stick 7.5\%, Rice straw $11.6 \%$, Rice husk $23.3 \%$, Bagasse 3.2\%, Firewood $10.4 \%$, Twigs and leaves $12.5 \%$ and other wastes $11.1 \%$ showed in figure 2 . Rice husk contributes biggest share of biomass energy and it was 83.04 PJ in 2003-2004. Energy production from rice husk is steadily increasing. But in the case of chemical no such type of data is found that is because chemical production rate from various biomass sources are not so much higher than energy. But it is a great hope that According to the reports of Bangladesh Bureau of Statistics (BBS) - 2005 this rate is increasing.

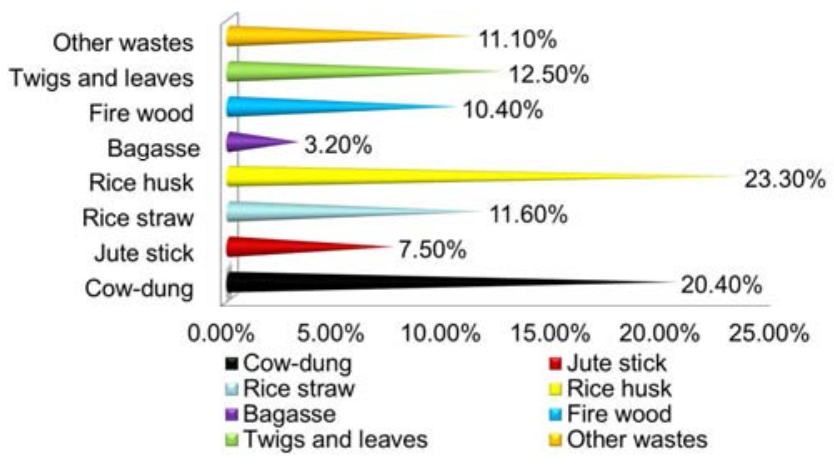

Figure 2. Contribution of different sources into total energy in Bangladesh.

\section{Conclusions}

The unstable rise of oil prices and the negative effects of petroleum on the environment have encouraged the search for new resources and techniques for chemical and energy production. The advantages of renewable resources towards sustainability of resources and low cost accelerated the development and utilization of abundant unused biomass for chemical and energy production. The advantages of using biomass rather than petroleum or others to manufacture chemicals and energy include opportunities for 
less pollution, no net $\mathrm{CO}_{2}$ contribution to the atmosphere, more biodegradable and sustainable products and, in some cases, lower cost. It has been found that many biomassderived chemicals and energy have economic advantages, particularly for some functionalized chemicals. On the other hands while environmental benefits of renewable energy are seen as a major advantage, the unit cost of producing renewable energy can be a deciding factor. But dedicated fundamental and applied research in both the public and private sectors will make renewable fuels and chemicals a reality in our future.

\section{References}

[1] Clark, J. H. and Deswarte. (2008). F. E. I., (Eds.), Introduction to chemicals from biomass, J. Wiley, 184:1213-1288.

[2] Demirbas, A. (2010). Biorefineries For Biomass Upgrading Facilities, Springer.

[3] Saga, K., Yokoyama, S., Imou, K., Kaizu, Y. (2008). A comparative study of the effect of $\mathrm{CO} 2$ emission reduction by several bioenergy production systems. Int Energy J, 9, 53-60.

[4] Biorefineries. (2005). Industrial processes and products. In: Ullmann's encyclopedia of industrial chemistry 4:101-133.

[5] Huber GW, Iborra S, Corma A. (2006). Synthesis of transportation fuels from biomass: chemistry, catalysts, and engineering. Chem Rev, 106, 4044-4098.

[6] Mäki-Arvela P, Holmbom B, Salmi T, Murzin DY. (2007). Recent progress in synthesis of fine and specialty chemicals from wood and other biomass by heterogeneous catalytic processes. Catal Re,v 49,197-340.

[7] Simone V. (2002) "Sustainable development, renewable resources and technological progress," CeFiMS Discussion Paper DP30. (www.cefims.ac.uk).

[8] Brown R. C. (2003). "Biorenewable resources: engineering new products from agriculture.” Ames, Iowa: Iowa State Press 4.

[9] U. S. EIA - Energy Information Administration: Annual Energy Outlook 2011 with Projections to 2035. (2011). Office of Integrated and International Energy Analysis, U. S. Department of Energy, Washington, DC 20585 246. Available at: $<$ http://www.eia.gov/forecasts/aeo/>.

[10] Hayes, D. J., Ross, J., Hayes, M. H. B., and Fitzpatrick, S. (2006). The Biofine Process: Production of Levulinic Acid, Furfural and Formic Acid from Lignocellulosic Feedstocks, in: B. Kamm, P. R. Gruber and M. Kamm (Ed.)^(Eds.), Biorefinery.

[11] Lange, J. P., Price, R., Ayoub, P. M., Louis, J., Petrus, L., Clarke, L., and Gosselink, H., Valeric. (2010). Biofuels: A Platform of Cellulosic Transportation Fuels, Angew. Chem.Int. Edit 49, 4479- 4483.

[12] Petersen, M. Ø., Larsen, J., and Thomsen, M. H. (2009). Optimization of hydrothermal pretreatment of wheat straw for production of bioethanol at low water consumption without addition of chemicals 33:834-840.

[13] Brehmer, B. and Sanders, J. (2009). Assessing the current Brazilian sugarcane industry and directing developments for maximum fossil fuel mitigation for the international petrochemical market, Biofuels Bioprod. Biorefining, 3: 347-360.

[14] Huang, Y. L., Wu, Z. T., Zhang, L. K., Cheung, C. M., and Yang, S. T. (2002). Production of carboxylic acids from hydrolyzed corn meal by immobilized cell fermentation in a fibrous-bed bioreactor, 82, 51-59.

[15] James H. C. and Fabien I. D. (2008). Introduction to chemical from biomass, John Wiley and Sons, United Kingdom.

[16] Werpy, T., and Petersen, G. (2004). Top Value Added Chemicals from Biomass: Results of Screening for Potential Candidates from Sugars and Synthesis Gas (U. S. Department of Energy Efficiency and Renewable Energy).

[17] F. Jin, Z. Zhou, A. Kishita, H. Enomoto, H. Kishidaand T. Moriya. (2007). A new hydrothermal process for producing acetic acid from biomass waste Chemical Engineering Research and Design,85(A2),201-206.

[18] Oh, H., Wee, Y.-J., Yun, J.-S., Ho Han, S., Jung, S., \& Ryu, H.-W. (2005). Lactic acid production from agricultural resources as cheap raw materials Bioresource Technology, 96 (13), 1492-8. doi:10.1016/j. biortech.2004.11.020.

[19] Richter, K., \& Berthold, C. (1998). Biotechnological Conversion of Sugar and Starchy Crops into Lactic Acid. Journal of Agricultural Engineering Research, 71 (2), 181191. doi:10.1006/jaer.1998.0314.

[20] Koutinas, A. A., Xu, Y., Wang, R., \& Webb, C. (2007). Polyhydroxybutyrate production from a novel feedstock derived from a wheat-based biorefinery. Enzyme and Microbial Technology, 40(5), 1035-1044. doi:10.1016/j.enzmictec.2006.08.002.

[21] John, R. P., Nampoothiri, K. M., \& Pandey, A.. (2006). Solidstate fermentation for 1-lactic acid production from agro wastes using Lactobacillus delbrueckii. Process Biochemistry, 41 (4), 759-763. doi:10.1016/j.procbio.2005.09.013.

[22] Wang, L., Zhao, B., Liu, B., Yang, C., Yu, B., Li, Q., Ma, Y. (2010). Efficient production of L-lactic acid from cassava powder by Lactobacillus rhamnosus. Bioresource Technology 101(20), 7895-901. doi:10.1016/j.biortech.2010.05.018.

[23] Marques, S., Santos, J. A. L., Gírio, F. M., \& Roseiro, J. C. (2008). Lactic acid production from recycled paper sludge by simultaneous saccharification.

[24] Narita, J., Nakahara, S., \& Fukuda, H. (2004)., Efficient Production of L - (+) -Lactic Acid from Raw Starch by Streptococcus bovis 97(6),423-425.

[25] Pagliaro, M., Ciriminna, R., Kimura, H., Rossi, M., and Della Pina, C. (2007). From glycerol to value-added products. Angew. Chem. Int. Ed. Engl, 46, 4434-4440.

[26] Wang, Z., Zhuge, J., Fang, H., and Prior, B. A. (2001). Glycerol production by microbial fermentation: a review. Biotechnol Adv, 19,201-223.

[27] Corma, A., Iborra, S., and Velty, A. (2007). Chemical routes for the transformation of biomass into chemicals. Chem. Rev, 107, 2411-2502.

[28] IEA. (2006). Renewables in Global Energy Supply. Paris: 15 p. International Energy Agency.

[29] Bauen, A. (2005). Biomass in Europe Bioenergy: Realizing the Potential. The Netherlands: Elsevier: 19-30. 
[30] ESRU (Energy Systems Research Unit). (2011). "What Is Biodiesel?" University of Strathclyde journal.

[31] Conley S. P., and B. Tao. (2011). "What Is biodiesel?" Purdue Extension 43-45.

[32] Ahmad, M.; Teong, L. K.; Sultana, S.; Zafar, M. (2016). Biodiesel production from non-food crops: a step towards self-reliance in energy Materials and processes for energy: communicating current research and technological developments. Badajoz, Spain: Formatex Research Cente, $r$ 239-243.

[33] Peyman Abdeshahian, Jeng Shiun Lim a, b, Wai Shin Ho, Haslenda Hashim, Chew Tin Leea, n. (2007). "Potential of biogas production from farm animal waste in Malaysia". Renewable and Sustainable Energy Reviews journal homepage: www.elsevier.com/locate/rser

[34] Rudianto Amirtaa, Elisa Herawatib, c, Wiwin Suwinartia, Takashi Watanabed. (2015). "Two-steps Utilization of Shorea Wood Waste Biomass for The Production of Oyster Mushroom and Biogas - A zero waste Approach" International Conference on Food, Agriculture and Natural Resources, ICFANRes 2015 The Authors. Published by Elsevier.

[35] Arkadiusz Piwowar, MaciejDzikuć, Janusz Adamczyk. (2016). "Agricultural biogas plants in Poland - selected technological, market and environment aspects." Renewable and Sustainable Energy Reviews 58:69-74.

[36] Cristina Rodriguez a, A. Alaswada, n, K. Y. Benyounis b, A. G. Olabi a. (2015)."Pretreatment techniques used in biogas production from grass." Renewable and Sustainable Energy Reviews, journal homepage: www.elsevier.com/locate/rser.

[37] Sim, J. H., Kamaruddin, A. H. (2008). Optimization of acetic acid production from synthesis gas by chemolithotrophic bacterium- Clostridium acetic using statistical approach. Bioresour. Technol, 99 (8), 2724-2735.

[38] Bothast, R., Schlicher, M. (2005). Biotechnological processes for conversion of corn into ethanol Appl. Microbiol. Biotechnol, 67 (1):19-25.

[39] Naik, S., Goud, V. V., Rout, P. K., Dalai, A. K. (2010). Production of first and second generation biofuels: A comprehensive review. Renew. Sustainable Energy Rev, 14 (2), 578-597.
[40] Field, C. B.; Behrenfeld, M. J.; Randerson, J. T.; Falkowski, P. (1998)., Primary production of the biosphere: integrating terrestrial and oceanic components. Science 281, 237-240.

[41] Walker, D. (2009). Biofuels, facts, fantasy, and feasibility. $J$. Appl. Physiol, 21, 509-517.

[42] Rajkumar, R.; Yaakob, Z.; Takriff, M. S. (2013). Potential of the micro and macro algae for biofuel production: A brief review. Bio Resources, 9, 1606-1633.

[43] Spolaore P, Joannis-Cassan C, Duran E, Isambert A. (2006). Commercial applications of microalgae. J Biosci Bioeng, 101, 87-96.

[44] Roessler PG, Brown LM, Dunahay TG, Heacox DA, Jarvis EE, Schneider JC. (1994). Genetic engineering approaches for enhanced production of biodiesel fuel from microalgae. ACS Symp Ser, 566, 255-70.

[45] Ghirardi ML, Zhang JP, Lee JW, Flynn T, Seibert M, Greenbaum E,. (2000). Microalgae: a green source of renewable H2. Trends Biotechnol, 18, 506-11.

[46] Cruz, V., Hernande, S., Martin, M., Grossmann, I. E. (2014). Integrated synthesis of biodiesel, bioethanol, isobutene, and glycerol ethers from algae. Ind. Eng. Chem. Res, 53 (37), 14397-14407.

[47] M. Rofiqul Islam, M. Rabiul Islam and M. Rafiqul Alam Beg. (2006). "Renewable energy resources and technologies practice in Bangladesh". Renewable and Sustainable Energy Reviews. doi:10.1016/j.rser.

[48] M. Ahiduzzaman. (2007). "Rice Husk Energy Technologies in Bangladesh". Agricultural Engineering International: the CIGR Ejournal. Invited Overview, 1 (1), 27-35.

[49] Guo X, Wang S, Wang Q, Guo Z, and Luo Z. (2011). "Properties of bio-oil from fast pyrolysis of rice husk, Biotechnology and Bioengineering," Chinese J Chem Eng; 19 (1),116-121

[50] Himadri R. G. (2011). "Biorefineries from the perspective of sustainability: Feedstocks, products, and Processes," Renew Sustain Energy Rev;15, 4042-4052

[51] Seon-Jin K, Su-Hwa J, and Joo-Sik K. (2010), "Fast pyrolysis of palm kernel shells: Influence of operation parameters on the bio-oil yield and the yield of phenol and phenolic compounds," Bioresour Technol 101, 9294-9300. 